\title{
IMPACT OF INTERNATIONAL TRADE ON EMPLOYMENT IN ORANGE INDUSTRY OF SOUTH AFRICA
}

\author{
Nkoti Solly Molepo ${ }^{1 \bowtie}$, Abenet Belete ${ }^{1}$, Jan Hlongwane ${ }^{1}$ \\ ${ }^{1}$ University of Limpopo, South Africa
}

\begin{abstract}
The purpose of the study is to analyse the long-run and short-run dynamic relations amongst total employment $\left(\ln E M P G_{t}\right)$, export output $\left(E X P O_{t}\right)$ and import output $\left(I M P O_{t}\right)$ from 1990 to 2018, by applying a time-series analysis. The study adopts the secondary data for total employment from the Citrus Growers Association of South Africa, while both export and import output were sourced from the Global Trade Atlas. The multivariate cointegration approach is adopted in the study to identify any causal relationships amongst the concerned variables. The chosen optimum lag selection criterion was the Akaike Information Criterion (AIC) due to its association dependence on the log-likelihood ratio. The third lag was selected for the entire analysis. The results from the cointegration test and the Vector Error Correction Model (VECM) suggest a positive long-run effect between total employment and export output, while import output is negatively associated with total employment. The adjustment term of $\ln E M P G_{t}$, $E X P O_{t}$ and $I M P O_{t}$ suggests that the previous year's errors are corrected for the current year at a convergence speed of 0.002 , 1.11 and 25.37 percentage points, respectively. The results of the Granger causality test show that there are bidirectional causality effects between export output and total employment in the long run, while there are no causality effects between import output and total employment. The overall conclusion is that export outputs positively impact employment, while import outputs impact it negatively in the South African orange industry.
\end{abstract}

Keywords: South African orange industry, employment, wages, international trade, Johansen cointegration, vector error correction model

\section{INTRODUCTION}

International trade and the global value chains stimulate employment opportunities, but employees are sometimes intimidated by the competition imposed by partner countries (Portella-Carbo, 2016). Furthermore, the advancement of both international trade and the global value chain of the fruit industry influence employment either negatively or positively (Idsardi and Cloete, 2013). South African oranges are marketed through different marketing channels both domestically and internationally. Notably, the South African orange industry is the largest sub-industry of citrus in both value and volume. CGA (2019) reported that during the 2017/18 production season, more than 77 million cartons (equivalent to 46 thousand containers) of oranges were exported. South Africa is globally ranked as the third-largest citrus exporter after Spain and Turkey in terms of value, while it is ranked 17th in volume produced (Kapuya, 2015)

International trade liberalisation in South Africa was followed by deregulations of markets and increased the use of casual and contract employment models (Sender and Johnston, 2004). The industry was deregulated in 1997, which led to reduced government support and the collapse of the price-setting mechanism (Sandrey and Vink, 2007). The deregulation exposed the orange industry to immense international competition; however, fresh oranges perform competitively; however, the country remains the importer of concentrates and other

\footnotetext{
$\bowtie$ Nkoti Solly Molepo, Department of Agricultural Economics and Animal Production, University of Limpopo, South Africa, e-mail: nonkie.molepo@gmail.com,https://orcid.org/0000-0001-5550-1759
} 
processed goods made from oranges. Irrespective of exposure to international markets, the industry employees are remunerated based on the minimum wage fixed around ZAR175 per day or ZAR3,500 per month. The amount is below the living wage of R6,252 per month (DAFF, 2018; Lubinga and Phaleng, 2018).

Based on the above discussion, this study attempts to empirically analyse the effects of employment on international trade flow in the South African orange industry. The study adopted the descriptive statistics, Johansen cointegration test, vector error correction model and Granger causality test to model the short-run and the long-run effects of international trade flow on employment. The remainder of the study comprises the literature review, succeeded by the methodology, empirical results, discussion and conclusions.

\section{LITERATURE REVIEW}

International trade liberalisation takes place when all types of trade barriers are eroded; it is based on two critical components, i.e. uniformity, which highlights that barriers to international trade, more particularly customs duties, that should be eliminated for every trading partner; and universality, which indicates that profits from international trade are available to all nations irrespective of their geographical and institutional situations. However, global trade benefits depend on various factors that affect employment and wages, such as geographical location, culture, factor endowments, history, labour market dynamics, and developmental stage (Bongsha, 2011).

Krugman (1979) postulates that if the argument of perfect competition is applicable, international trade liberalisation should benefit all nations and generate employment opportunities. However, markets are imperfect, which weakens the notion of international trade liberalisation. This argument does not imply that protectionism is a better setup than global trade liberalisation.

As postulated by (Porter, 1990), firms build their productivity if there is a direct international competition. Therefore, internationally competitive producers of primary and intermediate goods generate a massive advantage in downstream industries, including economies of scale, low production costs, sustainability and productivity. For instance, in South Africa, most production inputs (fuel, fertiliser, herbicides and pesticides) are sourced internationally, relying on multiple factors such as customs duties, exchange rates and transport costs. Nevertheless, exports of primary commodities tend to generate employment opportunities in the importing countries and negatively contribute to the balance of payments in the raw material exporting countries (Jayanthakumaran, 2006; Lubinga, 2014).

De Pinto and Michaelis (2014) conducted a study on the effects of international trade liberalisation on the labour market, including trade unions and heterogeneous labour based on the Melitz framework. Their findings highlight that employees are divided according to their skills. The core findings are as follows: (i) international trade liberalisation affects low-skilled employees negatively, which results in long-term unemployment after losing a job; (ii) high-skilled employees are capable of learning the latest technologies, and it is easier for them to transition to another industry outside agriculture; and (iii) countries with an abundance of low-skilled employees are affected by international trade liberalisation negatively, which results in the higher unemployment rate and severely harms the country's welfare (Salvanes and Forre, 2003).

\section{METHODOLOGY}

This section provides information about the study area, dataset sources, unit root test using the Augmented Dickey-Fuller (ADF) test, descriptive statistics and the inferential statistics methods. The statistical inference includes the Johansen integration test, assessing cointegration between the variables; The Vector Error Correction Method (VECM) was applied after the cointegration test. Lastly, the Granger causality test was used to determine the causality between variables.

\section{Study area}

This study focuses on the South African orange industry and its trading partners. The oranges in South Africa are produced chiefly in Eastern Cape, KwaZulu-Natal, Limpopo, Mpumalanga, and Western Cape. The leading orange producing areas in the Eastern Cape Province include Eastern Cape Midlands, Patensie and Sundays River Valley (DAFF, 2018) ${ }^{1}$. The main production areas in KwaZulu-Natal Province are KwaZulu-Natal

${ }^{1}$ DAFF was the South African Department of Agriculture, Forestry and Fisheries, now renamed the Department of Agriculture, Land Reform and Rural Development. 
Midlands, Nkwalini and Pongola. The production of oranges in Limpopo Province takes place at Groblersdal, Hoedspruit, Letsitele, Vhembe and Zebediela. The orange production areas in Mpumalanga Province are Nelspruit, Onderberg and Senwes. Lastly, in the Western Cape, oranges are produced at Boland and Ceres $(\mathrm{CGA}, 2019)^{2}$.

\section{Data sources}

The study utilised annual observations for the period between 1990 and 2018 to estimate the response of the South African orange industry to international trade. The dataset for employment was transformed into a natural logarithm in order to express them in percentages. The export and imports dataset was sourced from the Global Trade Atlas (GTA), while employment data was sourced from the Citrus Growers Association (CGA) of South Africa and the Bureau for Food and Agricultural Policy (BFAP). The employment, exports and imports are denoted by $\operatorname{lnEMPG_{t}}, E X P O_{t}$ and $I M P O_{t}$, respectively.

\section{Descriptive statistics}

Descriptive statistics are adopted to describe the features of the data quantitatively. Furthermore, the descriptive statistics provide simplified summaries concerning the observations included in the study. The study uses the following descriptive statistics to assess the properties of the data: minimum, maximum, mean, median and standard deviations. The minimum represents the smallest value of the series, while the maximum is the biggest value of the series. The mean is the commonly applied method of describing average tendency. Finally, the median is the score occurring in the middle of the series values.

\section{Unit root test}

The intuition is that macroeconomic time-series data usually suffer from non-stationarity (Mukhtar and Rasheed, 2010) and become susceptible to spurious regression. Therefore, we subject the time series to a stationarity test using ADF before cointegration analysis. The ADF test is based on the t-ratio of the parameter in the subsequent estimation.

$$
\Delta X_{t}=k+\varnothing+\Theta_{i} X_{t-i}+\sum_{t=1}^{n} \varphi_{i} \Delta X_{t-i}+\varepsilon_{t}
$$

\footnotetext{
${ }^{2} \mathrm{CGA}$ is an abbreviation for the Citrus Growers Association of South Africa, which the citrus growers developed immediately after the deregulation in 1997.
}

where: $X$ - denotes a concerned variable, $\Delta$ - represents the first difference operator, $t$ - signifies any time-related trend, $\varepsilon_{t}$ - denotes the random error term and $n-$ signifies the maximum lag length. The identified optimal lag is to guarantee that the disturbance term is white noise. The included terms such as $k, \varnothing, \Theta$ and $\varphi$ represent parameters to be assessed. When the null hypothesis of $\Theta=0$ cannot be rejected, then the conclusion is the series under assessment possess a unit root, and it is regarded as non-stationarity.

\section{Johansen cointegration analysis}

The cointegration analytical procedure was estimated using Stata version 14. The prerequisite for undertaking a cointegration analysis is dealing with optimal lag length because multivariate cointegration analysis, which the study adopts, is very sensitive to lag length selection. There are several criteria for lag length selection, namely: Final Prediction Error (FPE), Akaike Information Criterion (AIC), Hannan-Quinn Criterion (HQIC) and Schwarz's Bayesian Information Criterion (SBIC). However, the study adopts the AIC as the preferred criterion as it incorporates the constant term which emanates from the log-likelihood function. In addition, Stata applies the specific form of log-likelihood function (LL) for a Vector Autoregressive (VAR), as stated by (Mukhtar and Rasheed, 2010).

$$
L L=\left(\frac{T}{2}\right)\left\{\ln \left(\left|\Sigma^{\wedge-1}\right|\right)-K \ln (2 \pi)-K\right\}
$$

where: $T-$ denotes the number of observations, while $K-$ represents the number of included equations, $\Sigma^{\wedge}-$ signifies the maximum likelihood estimate of $E\left[u_{t} u_{t}\right]$ where $u_{t}$-resembles the $K \times 1$ vector of disturbances. The justification is that:

$$
\ln \left(\left|\Sigma^{\wedge-1}\right|\right)=-\ln \left(\left|\Sigma^{\wedge}\right|\right)
$$

Therefore, the log-likelihood can be rewritten as follows:

$$
L L=-\left(\frac{T}{2}\right)\left\{\ln \left(\left|\Sigma^{\wedge}\right|\right)+K \ln (2 \pi)+K\right\}
$$

Stata programme applies the subsequent definitions of AIC function grounded on the log-likelihood function displayed above.

$$
A I C(p)=-2\left(\frac{L L}{T}\right)+2 \frac{t}{T}
$$


where: $T$ - represents the number of observations, $L L-$ denotes the log-likelihood for VAR, and $p$ - stands for the number of lags.

Normally preference is directed to the model with fewer parameter to regress, provided that those candidate models are separately specified correctly. Hence, it is referred to as the most parsimonious model. The AIC selects the correctly set model asymptotically because it considers the model with a greater value of the log-likelihood function (Zheng et al., 2020). After performing the Johansen cointegration test, the VECM was regressed using the selected optimal lag length.

\section{Vector Error Correction Model}

The VECM is a statistical procedure meant to analyse the long-run equilibrium dynamics within the time series. The model falls under a set of multiple time series analytical techniques mainly applied for a dataset where the key variables have a long-run stochastic trend; the process is known as cointegration. Furthermore, the error correction term (ECT) adheres to how the previous year's deviation from the long-run equilibrium impacts its short-run dynamics. In a nutshell, the VECM estimates the speed at which the explanatory variables converge to equilibrium (Jain and Gupta, 2019). The general VECM is expressed as follows:

$$
\Delta Y_{t}=\beta_{0}+\sum_{i=0}^{n} \beta_{i} \Delta y_{t-1}+\sum_{i=0}^{n} \delta \Delta x_{t-1}+\varphi z_{t-1}+\varepsilon_{t}
$$

where: $Y-$ is the dependent variable, $\beta_{0}$ - represents the constant term, $\Sigma$ - denotes the summation, $\beta_{i}$ - represents the coefficients of the variables under consideration, $\Delta y_{t-1}-$ is percentage change on the lagged dependent variable, $\delta \Delta x_{t-1}-$ signifies percentage change on the lagged explanatory variables, $\varphi z_{t-1}-$ denotes the error correction term (the speed of adjustment) and $\varepsilon_{t}-$ is the disturbance term.

The specific VECM is as follows:

$$
\begin{gathered}
\Delta \operatorname{lnEMPGt}=\beta_{0}+\beta_{1} \Delta \ln E M P G_{t-1}+\beta_{2} \Delta \ln E M P G_{t-2}+ \\
+\beta_{3} E M P G_{t-3}+\beta_{4} \Delta \ln E X P O_{t-1}+\beta_{5} E X P O_{t-2}+ \\
+\beta_{6} \Delta E X P O_{t-3}+\beta_{7} \Delta \ln I M P O_{t-1}+\beta_{8} \Delta \operatorname{lnIMPO} O_{t-2}+ \\
+\beta_{9} I M P O_{t-3}+\theta E C_{t-1}+\varepsilon_{t}
\end{gathered}
$$

where: $\ln E M P G$ - represents the logarithm of total employment in the orange industry of South Africa, $\Delta-$ represent the differencing notation, $t$-denotes the time dimension, $\beta_{0}$ - signifies the constant term, EXPO - is the export output, IMPO - denotes the import output, $\theta E C_{t-1}$ - is the error correction term (the speed of adjustment) and $\varepsilon_{t}-$ is the disturbance term.

\section{Granger causality test}

The study adopts the Granger causality test to check for long-run causality amongst variables $\left(\ln E M P G_{t}, E X P O_{t}\right.$ and $\left.I M P O_{t}\right)$ and the direction of causation. Gujarati (2003) argues that the simplest Granger causality test involves at least two variables and their lags. Notably, the Granger causality test assists in establishing whether the movement in one variable causes the movement on the other variable. The Granger causality test determines whether the previous information from other variables could predict a series.

\section{EMPIRICAL RESULTS AND DISCUSSION}

The empirical results are presented and discussed in this section. It commences with the descriptive statistics, followed by the unit root test. After that, the Johansen cointegration test results are described, and the VECM and Granger causality test are discussed. Finally, the model normality checks are shown to test the strength of the econometric analysis.

\section{Descriptive statistics}

Table 1 shows that the average employment in the orange industry for the period under consideration is 19,000 , while the average export output is equivalent to R3 billion per annum, and the average import output is about R8 million per annum. The standard deviation for $E M P G_{t}, E X P O_{t}$ and $I M P O_{t}$ is equivalent to $0.23,0.31$ and 0.12 , respectively. The median values for $E M P G_{t}$, $E X P O_{t}$ and $I M P O_{t}$ are $0.01,1.7$ and 0.21 , respectively. The minimum employment recorded is 14,850 , while that of export output is R2.5 billion and for import

Table 1. The descriptive statistics of the orange industry dataset

\begin{tabular}{lllllc}
\hline Variable & $\begin{array}{c}\text { Mini- } \\
\text { mum }\end{array}$ & $\begin{array}{c}\text { Maxi- } \\
\text { mum }\end{array}$ & Mean & Median & $\begin{array}{c}\text { Standard } \\
\text { deviation }\end{array}$ \\
\hline$E M P G_{t}$ & 0.015 & 0.024 & 0.019 & 0.01 & 0.23 \\
$E P O_{t}$ & 2.5 & 11 & 3 & 1.7 & 0.31 \\
${I M P O_{t}}$ & 0.096 & 51 & 8 & 0.21 & 0.12 \\
\hline
\end{tabular}

Source: own elaboration based on the orange dataset. 
Molepo, N. S., Belete, A., Hlongwane, J. (2021). Impact of international trade on employment in orange industry of South Africa. J. Agribus. Rural Dev., 2(60), 193-201. http://dx.doi.org/10.17306/J.JARD.2021.01386

Table 2. Unit root test for orange variables using ADF test

\begin{tabular}{|c|c|c|c|c|c|}
\hline \multirow{3}{*}{ Variables } & \multicolumn{4}{|c|}{ Order of integration } & \multirow{3}{*}{ Conclusion } \\
\hline & \multicolumn{2}{|c|}{ level $[\mathrm{I}(0)]$} & \multicolumn{2}{|c|}{ first difference $[\mathrm{I}(1)]$} & \\
\hline & $t$-stats & critical value $(5 \%)$ & $t$-stats & critical value $(5 \%)$ & \\
\hline $\ln E M P G_{t}$ & -2.205 & -2.972 & $-4.764 * * *$ & -2.976 & Stationary at $I(1)$ \\
\hline$E X P O_{t}$ & 2.093 & -3.588 & $-6.358 * * *$ & -3.588 & Stationary at $I(1)$ \\
\hline$I M P O_{t}$ & 2.190 & -3.005 & $5.190 * * *$ & -3.005 & Stationary at $I(1)$ \\
\hline
\end{tabular}

Notes: the variation between the calculated $t$-statistics and critical value at $5 \%(p \leq 0.05)$ is used to test the presence of a unit root, $* * *$ denotes rejection of hypothesis for unit root at $1 \%(p \leq 0.01)$.

Source: own elaboration.

output is R96,000 per annum. The maximum employment is about 24,000, while export output is R11 billion per annum and import output is R51 million per annum.

\section{Unit root test}

The initial step prior to estimation of the Johansen cointegration analysis was to assess the unit root for each variable 3 . We adopted the ADF unit root test in a logarithmic form for the total employment in the orange industry $\left(\ln E M P G_{t}\right)$, while the export output $\left(E X P O_{t}\right)$ and import output $\left(I M P O_{t}\right)$ are considered in their original format. Table 1 shows the ADF results for the level $[I(0)]$ and the first difference $[I(1)]$ of the identified variables. The result suggests that stationarity tests conducted on all the orange industry variables at levels have failed to reject the null hypothesis of non-stationarity. Therefore, the conclusion is that all identified variables are non-stationary at levels. However, we reject the null hypothesis of non-stationarity when the series is first differenced $[I(1)]$.

\section{Johansen cointegration}

The study adopted the AIC criterion to select an optimal lag length for the Johansen cointegration analysis. Table 3 shows that the study needs to adopt the third lag length as optimal. The implication is that a third lag length would be used for the entire analysis. The AIC

\footnotetext{
${ }^{3}$ The Johansen cointegration procedure is identifies a stationary linear arrangement of a set of the identified variables. A prerequisite for cointegration to hold is that every variable needs to be non-stationary (Wooldridge, 2013).
}

Table 3. The lag selection criterion for the orange industry

\begin{tabular}{ccccccc}
\hline Lag & LogL & $L R$ & FPE & AIC & HQIC & SBIC \\
\hline 0 & -908 & NA & 1.8 & 75.89 & 75.93 & 76.36 \\
1 & -897 & 20.92 & $1.6^{*}$ & 75.77 & $75.93^{*}$ & $76.04^{*}$ \\
2 & -889 & 17.33 & 1.8 & 75.80 & 76.07 & 76.83 \\
3 & -867 & $29.62^{*}$ & 1.9 & $75.52^{*}$ & 76.03 & 77.44 \\
4 & -882 & 12.97 & 2.4 & 76.01 & 76.40 & 77.48 \\
\hline
\end{tabular}

*Indicates the selected optimal lag length based on each criterion. Source: own elaboration.

criterion chooses the most parsimonious model asymptotically as it is based on the log-likelihood function.

The Johansen cointegration test was estimated utilising non-correlated errors based on the optimal lag length selection criterion (Rasiah et al., 2015). Based on Table 1, all identified variables in the series are first differenced as there is more likelihood of an equilibrium connection. Therefore, the null hypothesis of no cointegration is rejected when the trace statistics give a critical value lower than 5\% (Gujarati, 2015). The decision criterion is that the null hypothesis of no cointegration cannot be rejected when the trace statistics reveal a critical value greater than $5 \%$.

Furthermore, the Johansen cointegration test was adopted to assess the occurrence of a long-run equilibrium relationship amongst the identified variables. Table 4 evaluates the trend of long-run relationships amongst total employment, export output and import output. Notably, as depicted in Table 4, trace statistics reveal at least two cointegrating equations from our model as the 
Table 4. The estimation of Johansen cointegrating errors for the orange industry

\begin{tabular}{lccc}
\hline $\begin{array}{c}\text { Hypothesis } \\
\text { No. of CE(s) }\end{array}$ & Eigenvalues & Trace statistics & Critic value \\
\hline None & 0.40 & 29.80 & 21.68 \\
At most 1 & 0.25 & 15.49 & 7.72 \\
At most 2 & 0.004 & 0.12 & $3.84^{*}$ \\
\hline
\end{tabular}

The results highlight the presence of two cointegrating equation in this model; * represents the cointegrating equation.

Source: own elaboration.

results are lower than the $5 \%$ critical value. Therefore, the results confirm a long-run cointegrating association amongst total employment, export output and import output.

After establishing that all included variables are stationary at the first difference $[I(1)]$ and cointegrated, a VECM containing at least two cointegrating association and three lags in each was performed. The VECM suggests the long-run effects of the endogenous variables to converge to their long-run equilibrium while permitting an extensive range of short-run dynamics. Table 5 shows that the coefficient associated with an ECT for total employment, which possesses the correct signage, while it is statistically significant at $10 \%$ and its speed of convergence towards equilibrium is $0.2 \%$.

Therefore, in the short run, total employment is adjusted by $0.2 \%$ of the previous year's derogation from the equilibrium. The high values of the ECT coefficient highlight that equilibrium agents eliminate a large percentage of disequilibrium pertaining to each period, i.e. the adjustment speed is regarded as faster in this instance. However, the low absolute values are associated with the slow speed of convergence towards equilibrium. Nonetheless, the rate of adjustment for total employment towards equilibrium is sluggish. The other variables included in the estimation are the lagged total employment $\left(\ln E M P G_{t-1}, \ln E M P G_{t-2}\right.$ and $\left.\ln E M P G_{t-3}\right)$, which are statistically insignificant and have a negative sign except for $\ln E M P G_{t-1}$.

The ECT coefficient of export output carries a negative sign, and it is statistically significant at a $1 \%$ level. Furthermore, the coefficient of the ECT has at least a $1.11 \%$ speed of adjustment to equilibrium. Therefore, the implication is that the short-run export output is converging by $1.11 \%$ of last year's deviation from equilibrium. This suggests that the system is stable, and the speed of adjustment towards equilibrium is slow.

The coefficient of ECT associated with import output demonstrates a negative sign, and it is statistically significant at a $1 \%$ level. Nevertheless, the results show the stableness of the system and smooth adjustment towards equilibrium. Furthermore, the convergence to the equilibrium path would be faster due to the considerable ECT value of approximately 25.37. In a nutshell, the statistical significance of all coefficients associated with ECTs for an individual time series suggests that they entirely influence one another in the long run.

The results presented in Table 5 highlight that the fitted degree of VECM's $\mathrm{R}^{2}$ is equivalent to $0.45,0.88$ and 0.45 , respectively. The AIC and $S B I C$ values are relatively small, i.e. 75.62 and 77.33 , respectively. The log-likelihood value is about 910.26 , which is much greater than AIC and SBIC, showing the strength of the model. The $\mathrm{R}^{2}$ value of total employment highlights that all included variables explain $45 \%$ of the total employment equation variations. For the export output equation, $88 \%$ of variations in the equation are clarified by included variables. Table 5 suggests that all lagged variables explain $45 \%$ of variations in import output.

\section{Normality test}

Table 6 presents the Johansen normalisation restrictions, which are often called the long-run equation. The restriction is based on our target variable: total employment, as illustrated in Table 6 . The results indicate that the t-statistics for the $I M P O_{t}$ series with reaction to ${\ln E M P G_{t}}_{t}$ are statistically significant, while the $E X P O_{t}$ series is statistically insignificant. Notably, the sign for the statistically significant normalised cointegrating coefficient is reversed when interpreted. However, the sign of the coefficient for statistically insignificant $E X P O_{t} \mathrm{se}-$ ries is captured as it appeared. The cointegrated equation and the t-statistics allow the identification of the degree and direction of impact generated by import output on the total employment in the orange industry of South Africa. As presented in Table 6, the results suggest that a $1 \%$ increase in import output leads to a decrease of $3.05 \%$ in total employment in the long run. Notably, a $1 \%$ increase in export output leads to a 2.10 increase in total employment in the long run. The decision is that the export output has a positive long-run effect on total employment, while the import output shows negative long-run effects on total employment, ceteris paribus. 
Molepo, N. S., Belete, A., Hlongwane, J. (2021). Impact of international trade on employment in orange industry of South Africa. J. Agribus. Rural Dev., 2(60), 193-201. http://dx.doi.org/10.17306/J.JARD.2021.01386

Table 5. The VECM estimation results for the orange industry

\begin{tabular}{|c|c|c|c|}
\hline Error correction & $D(\ln E M P G)$ & $D(E X P O)$ & $D(I M P O)$ \\
\hline EC term (speed of adjustment) & $-0.002 *(-2.23)$ & $-1.11 * * *(-3.56)$ & $-25.37 * * *(-2.71)$ \\
\hline $\ln E M P G_{t-1}$ & $0.16(0.59)$ & $-3.90(-0.48)$ & $1.16(0.47)$ \\
\hline $\ln E M P G_{t-2}$ & $-0.002(-0.01)$ & $-1.51 *(-1.78)$ & $1.36(0.53)$ \\
\hline $\ln E M P G_{t-3}$ & $-0.07(-0.26)$ & $1.50(0.17)$ & $1.22(0.47)$ \\
\hline$E X P O_{t-1}$ & $4.19(0.42)$ & $-0.93 * * *(-3.01)$ & $-0.01(-1.45)$ \\
\hline$E X P O_{t-2}$ & $2.18(0.26)$ & $-0.29(-1.12)$ & $-0.01 *(-1.80)$ \\
\hline$E X P O_{t-3}$ & $-3.40(-0.42)$ & $-0.26(-1.04)$ & $-0.01 *(-1.90)$ \\
\hline$I M P O_{t-1}$ & $-7.39(-1.51)$ & $58.07 * * *(3.85)$ & $0.61(1.35)$ \\
\hline$I M P O_{t-2}$ & $-3.65(-0.62)$ & $75.95 * * *(4.15)$ & $0.81(1.46)$ \\
\hline$I M P O_{t-3}$ & $-3.45(-0.49)$ & $54.04(2.47)$ & $0.71(1.08)$ \\
\hline Constant & $-0.003(-0.08)$ & $94.28(0.00)$ & $-41.10(-1.15)$ \\
\hline R-squared & 0.45 & 0.88 & 0.45 \\
\hline Log-likelihood & & -910.26 & \\
\hline Akaike information criterion & & 75.62 & \\
\hline Schwarz information criterion & & 77.33 & \\
\hline
\end{tabular}

Notes: Robust statistics are presented in parenthesis below coefficients, ${ }^{* * *}$ denotes significance at $1 \%$ level $(p \leq 0.01),{ }^{* *}$ denotes significance at $5 \%$ level $(p \leq 0.05)$ and $*$ represents a $10 \%$ significance level $(p \leq 0.1)$. Source: own elaboration.

Table 6. The normalised cointegrating coefficients for the orange industry

\begin{tabular}{cc}
\hline Cointegrating equation & CointEq1 \\
\hline $\ln E M P G_{t}$ & 1.00 \\
$E X P O_{t}$ & 2.10 \\
& $(0.71)$ \\
& $3.05^{* * *}$ \\
& $(4.48)$ \\
\hline
\end{tabular}

*** denotes statistical significance at $1 \%$ level, while the sign of the significant coefficient is reversely interpreted, and the signs of the insignificant coefficient are interpreted as they appear. Source: own elaboration.

The Lagrange Multiplier (LM) test was adopted to check for autocorrelation on the lag order of the estimation. The decision rule for the LM test is that the null hypothesis for no autocorrelation is rejected when the probability value is below $5 \%$. However, the alternative
Table 7. The LM test for autocorrelation

\begin{tabular}{ccc}
\hline Lag & $x^{2}$ & Probability \\
\hline 1 & 19.87 & 0.08 \\
2 & 16.20 & 0.06 \\
3 & 12.08 & 0.21 \\
\hline
\end{tabular}

Source: own compilation

hypothesis for no autocorrelation cannot be rejected when the $\mathrm{p}$-value is greater than $5 \%$. Table 7 shows that the null hypothesis of no autocorrelation cannot be rejected because all the p-values exceed 5\%. Therefore, all the third lags are free from autocorrelation, which renders the estimation robust.

Table 8 highlights the test for normally distributed disturbances using the Jarque-Bera test. The decision rule is that the disturbances are normally distributed when the probability value is more than $5 \%$, while the 
Table 8. The Jarque-Bera test for the orange industry

\begin{tabular}{lcc}
\hline \multicolumn{1}{c}{ Equation } & $x^{2}$ & Probability \\
\hline$D \ln E M P G_{t}$ & 1.27 & 0.52976 \\
$D \ln E X P O_{t}$ & 0.87 & 0.64715 \\
$D_{\operatorname{lnIMPO}}$ & 44.06 & 0.00000 \\
$\mathrm{ALL}$ & 46.20 & 0.52631 \\
\hline
\end{tabular}

Source: own compilation.

disturbances are not normally distributed when the $p$ -value is lower than $5 \%$. The results highlight that the disturbances are normally distributed for the total employment equation, export output and the entire model. However, the errors are not normally distributed only for import output.

Table 9 presents the results for the model stability condition of VECM estimates. The results show that the VECM specification imposes at least two unit moduli, which are represented on both eigenvalue and modulus. The estimates satisfy the eigenvalue stability condition because the modulus of individual eigenvalue is strictly below 1, except for only two conditions. Therefore, the test for stability condition indicates that the model is stable.

Table 9. Eigenvalue stability condition

\begin{tabular}{ll}
\hline \multicolumn{1}{c}{ Eigenvalue } & Modulus \\
\hline $0.7126087+0.9002103 \mathrm{i}$ & 0.14812 \\
$0.7126087-0.9002103 \mathrm{i}$ & 0.14812 \\
0.050946 & 0.05095 \\
1 & 1 \\
1 & 1 \\
$-0.8356735+0.334111 \mathrm{i}$ & 0.899989 \\
$-0.8356735-0.334111 \mathrm{i}$ & 0.899989 \\
$-0.4527786+0.7138282 \mathrm{i}$ & 0.845316 \\
$-0.4527786-0.7138282 \mathrm{i}$ & 0.845316 \\
$0.2255524+0.4870533 \mathrm{i}$ & 0.536745 \\
$0.2255524-0.4870533 \mathrm{i}$ & 0.536745 \\
-0.2836746 & 0.283675 \\
\hline
\end{tabular}

Source: own compilation.

\section{Granger causality test}

The study adopts the Granger causality test to assess the causality effects amongst the variables. Table 10 illustrates the unsurprising bidirectional causality effects between total employment and export output because their $p$-values are below 0.05 . It is attributed to the fact that export results in profitability which induces orange producers to increase productivity by employing more people. However, there are no causality effects between import output and total employment, even between export output and import output.

Table 10. Granger causality test for the orange industry

\begin{tabular}{lcc}
\hline \multicolumn{1}{c}{ Null hypothesis } & $F$-statistic & $P$-value \\
\hline EXPO no Granger Cause LNEMPG & 5.30 & 0.0132 \\
LNEMPG no Granger Cause EXPO & 10.39 & 0.0067 \\
IMPO no Granger Cause LNEMPG & 0.35 & 0.7105 \\
LNEMPG no Granger Cause IMPO & 0.28 & 0.7588 \\
IMPO no Granger Cause EXPO & 2.12 & 0.1438 \\
EXPO no Granger Cause IMPO & 1.61 & 0.2224 \\
\hline
\end{tabular}

The relationship with $p$-values below $0.05 \%$ signifies the causality effects between the variables, while the relationship with a $p$ -value over $0.05 \%$ denotes no causality between the variables. Source: own elaboration.

\section{CONCLUSIONS}

This study is one of the very few studies, which have empirically analysed the short-run and long-run effects of international trade flow on total employment in the orange industry of South Africa. The empirical analysis is based on the annual time series dataset during the period between 1990 and 2018. The unit root test of the series was employed using the ADF before executing the inferential estimation. The ADF test highlighted that all variables were found to be stationary in the first differences. The descriptive statistics, Johansen cointegration, the VECM and the Granger causality test were applied to analyse the effect of international trade on employment. The research findings show that export output has a positive short-run effect on total employment. The interpretation is that when the export output of oranges increases, the total employment in the industry rises. Furthermore, the results show that the import 
output has a negative short-run effect on total employment. The implication is that when the import output of oranges increases, the total employment decreases. However, in the long run, the export output positively affects total employment, while imports have a negative effect. In conclusion, export output and import output have asymmetric effects on total employment in the long run, ceteris paribus. There are long-term causality effects of export output on the total employment in the long run, while there are short-term causality effects of import output on total employment in the long run.

In a nutshell, because the export output positively affects the total employment in the orange industry of South Africa, it is recommended that the government of South Africa, in collaboration with the Citrus Growers Association, support export initiatives by availing subsidies and non-financial supports in three government spheres. In addition, the government should open more markets for South African oranges in Africa and across the world. Finally, the authors recommend further studies on cost drivers of orange exports faced by the South African value chain actors.

\section{ACKNOWLEDGEMENT}

The authors would like to acknowledge the immeasurable support provided by the Citrus Growers Association of South Africa; the Department of Agriculture, Land Reform and Rural Development; the Department of Trade, Industry and Competition; the University of Limpopo and the National Agricultural Marketing Council.

\section{REFERENCES}

Bongsha, B. (2011). The impact of trade liberalisation on the manufacturing sector in Cameroon. University of North West.

CGA (2019). 2019 Industry Statistics, 2018 Export Season. Hilcrest, KwaZulu Natal. Retrieved June $12^{\text {th }} 2020$ from: www.cga.co.za

DAFF (2018). A profile of the South African citrus market value chain, Pretoria, South Africa. Retrieved from: www. daff.gov.za

De Pinto, M., Michaelis, J. (2014). International trade and unemployment - the worker-selection effect. Rev. Int. Econ., 22(2), 226-252.

Gujarati, D.N. (2003). Basic econometrics. New York: The McGraw-Hill Companies.
Gujarati, D.N. (2015). Econometrics by example. New York: Palgrave Macmillan.

Idsardi, E.F., Cloete, P.C. (2013). A historical perspective of the link between economic recessions and agricultural trade performance: The case of South Africa's fruit and wine exports. Agrekon, 52(4), 43-65.

Jain, M., Gupta, H. (2019). A Vector Error Correction Model (VECM) approach to investigate the linear behaviour of stocks, bonds and hedge funds, Moradabad, India. Retrieved from: www.iftmuniversity.ac.za

Jayanthakumaran, K. (2006). An empirical assessment of the effects of trade on employment in Australia 1989/19902000/2001. Econ. Pap., 25(1), 68-82.

Kapuya, T. (2015). The trade effects of technical barriers on South Africa â€TM s orange exports. Agrekon, 54(1), 1-27.

Krugman, P. (1979). Increasing returns, monopolistic competition and international trade. J. Int. Econ., 9(1), 469-479.

Lubinga, M.H. (2014). The impact of climate change and the european union gsp-scheme on east africa's horticultural trade. Bloemfontein, South Africa. University of the Free State. Retrieved fron: www.ufs.ac.za

Lubinga, M., Phaleng, L. (2018). South African fruit trade flow. National Agricultural Marketing Council, Pretoria, Trade Probe, South Africa (pp. 3-10).

Mukhtar, T., Rasheed, S. (2010). Testing long run relationship between exports and imports: evidence from Pakistan. J. Econ. Coop. Dev., 31(1), 41-58.

Portella-Carbo, F. (2016). Effects of international trade on domestic employment : an application of a global multiregional input - output supermultiplier model. Econ. Syst. Res., 28(1), 1469-5758.

Porter, M.E. (1990). The Competitive Advantage of Nations. Harvard: Harvard Business School.

Rasiah, R., Hamid, B.A., Seong, W.C.O., Habibullah, M. (2015). Time series analysis of the impact of consumption and energy use of environmental degradation: evidence from Malaysia. Kajian Malay., 33(1), 15-32.

Salvanes, K., Forre, S. (2003). Effects on employment of trade and technical change: evidence from Norway. Economica, 70(1), 293-329.

Sandrey, R., Vink, N. (2007). The deregulation of agricultural markets in South Africa and New Zealand: a comparison. Agrekon, 46(3), 323-350.

Sender, J., Johnston, D. (2004). Searching for a weapon of mass production in rural Africa : unconvincing arguments for land reform. J. Agrar. Change, 4(2), 142-164.

Wooldridge, J. (2013). Introductory econometrics: A modern approach. Michigan State, United States: South-Western Cengage learning.

Zheng, C., Bhowmik, P.K., Sarker, N. (2020). Industry-specific and macroeconomic determinants of non-performing loans: A comparative analysis of ARDL and VECM. Sustainability, 12(1), 1-17. 